\title{
Catch Them Young in Basic Science and Technology Education through Child-to-Child Approach
}

\author{
Dr. Folashade Afolabi \\ Department of Special Education and Curriculum Studies \\ Adeyemi College of Education, Ondo, Ondo State, Nigeria \\ afolabigrace13@yahoo.com, +2348033682979
}

\section{Doi:10.5901/jesr.2013.v3n7p38}

\begin{abstract}
If science and technology hold the key to sustainable development in the world and in Africa, this revelation should constitute a beacon to Nigeria as a nation. The corollary is that prominence must be given to science education in Nigerian schools at the early stage. Many researchers in science education have investigated challenges facing advancement in science and technology education in Nigeria and poor enrolment but found out that one of the major reasons is, that the interest of the learners are not sustained at the early stage. Teaching science at basic level could be a challenge. Science and technology teachers teaching young children need to develop a teaching strategy that will facilitate powerful learning experiences which will inspire deeper investigations that will validate and empower children to learn. This paper focuses on Hands-on science activities through child to child approach as essential components of an early childhood setting in basic science and technology education which may help in laying an early foundation for life-long learning and acquisition of science process skills.
\end{abstract}

Keywords: Catch them young, Basic science and technology, Child-to-Child approach, Action learning strategy, Conventional method, Nigeria

\section{Introduction}

Teachers are the most influential agent in the teaching and learning process in the classroom; both teaching and learning depend on the teacher. Any inadequacies in the teacher classroom practices are likely to influence the achievement and attitude of the learner since students are produced after them (Olakulehin, 2007). Often times underachievement recorded in students' performance are always linked to inability on the part of the students to comprehend what has been taught neglecting the fact that the totality of what takes place around the learner amount to what influences the learners' performances most especially the teacher and his classroom practices. This is evident in students' achievement in sciences subjects in Nigeria and most developing nations.

Science and technology have been identified as instruments for solving socio-economic problems and myriads of problems affecting developing nations of the world. Science and its application (technology) have brought great gains to most developed countries which have been nurtured to an enviable position. For any nation to develop, the corollary is that prominence must be given to science and technology education in schools at the early stage which laid the basic foundation for its growth. Momoh (2001) stated that primary education is the foundation of formal education on which the subsequent levels of the nation's education system rest. In the same vein, Maduabum (1991) affirmed that primary education is the bedrock of our educational continuum and it requires a solid foundation in science. The crisis of underachievement and enrolment in science courses could be linked to lack of solid foundation in sciences at the basic levels (Yoloye, 1994).

In response to this, various attempts have been made to improve the delivery and relevance of science, technology and mathematics education in Nigeria. To purse this, the Nigerian government formulated its policy on science and technology called the Nigerian National Policy on Science and Technology which was prepared for a frame work of twenty-five years and to be reviewed in every five years. More so, basic science and technology subject has been made compulsory subject to be taught at all basic levels. With these efforts, less than 40 per cent achievements have been realised (Ajiboye and Afolabi, 2012). This is an indication that there is need for effective instruction where knowledge will be created through transformation of experience to improve learning (Kolb, 1984). A major problem identified is the teacher and his/her methods of instruction. It has been reported that the methods of instruction in the classroom cannot effectively teach the contents of the curriculum therefore, no significant improvement recorded over the 
years. This study intends to make use of instructional approaches to teach the concept of energy in the curriculum probably there might be a notable improvement in achievement and attitude.

Child-to-child approach refers to a style of child empowerment where children are active participants in their own development and the development of other children (Pridmore \& Stephens, 2000). This approach is based on the belief that children from whatever circumstances are capable of helping themselves. This is on the premise that children will gain more from their development if they are active participants in the development process rather than passive recipients. According to Mwebi (2012) child-to-child approach is built on ideas inherent in Freiran empowerment theory (Freire, 1970), that advocated for a problem-posing education. Child-to-child approach has been used in Uganda and Nepal successfully to improve the environmental health of schools and enhanced leadership roles regarding children's right (Pridmore \& Stephens, 2000), in Botswana the child-to-child approach has helped school children prepare preschool children for entry into primary schooling (Pridmore \& Stephens, 2000). It is believed that if this approach is used effectively it might improve the attitude and achievement of basic level pupils in the concept of energy.

Action-learning strategy is an instructional strategy that has been recognized as an important strategy that enhances science learning in students (Sawchuk, 2003). Action learning is an educational process whereby the participants study their own actions and experience in order to improve performance (Marquardt, 2004; Chambers and Hale, 2007; Kramer, 2007). This is done in conjunction with others, in small groups called action learning sets. It is proposed as particularly suitable for all learners, as it enables each person to reflect on and review the action they have taken and the learning points arrived at, so as to guide future action and improve performance. The strategy stands in contrast with the traditional teaching methods that focus on the presentation of knowledge and skills. Action learning focuses on research into action taken, and the knowledge that emerges as a result, would lead to the improvement of skills and achievement. This is in agreement with constructivist theory that viewed knowledge as being constructed by individuals through their own experience within the world. This approach to learning emphasizes the use of authentic, challenging problems where learners make meaning through active participation (Jonassen, 1991). The author further stated that thinking is grounded in perception of physical and social experiences and that learning is a function of how the individual creates meaning from his or her experiences. In a constructivist learning environment, the role of the teacher, learner, content/ context and assessment vary significantly from the traditional class setting.

Young children, particularly those between three to eight years of age, learn best through doing (Edwards, Gandwin \& Forman, 1998). Abstract thoughts and concepts are difficult for them to grasp because they primarily learn about the world around them by experiencing it through their senses. For this reason, it is important to focus science lessons around things that they can see, hear, touch, taste, and smell so that they are continually immersed in science as they discover all sorts of new and different things about the world around them, how things work, and about themselves and others (Edwrds, Gandwin \& Forman, 1998) .

Literatures have revealed that students' attitudes toward science and technology and its choice are affected by teaching methods, perceived difficulty and gender (Simon, 2000). Ebenezer and Zoller (1993) reported that the most important variable affecting students' attitude towards school science was the kind of science instruction they experienced. This is supported by the findings of Alao (1990), Sunberg and Dini (1994); Ogunleye (1999) and Akinbobola (2008). Akinbobola (2008) showed that $64 \%$ of the total variance in the attitude of students towards the concept of heat energy in Physics is attributable to the influence of instructional materials used in teaching the students. Also, Akinbobola (2009) stated that $61 \%$ of the variance in the attitude of students in Physics is attributable to the influence of the instructional strategies. These studies seem to indicate that learners' interest/ attitude could be influenced negatively or positively by the teachers' choice of instructional approaches.

Gender has also been one of the prominent factors that influence achievement of students in science (Furner and Duffy, 2002). There have been conflicting findings by researchers (Baird, 1997; Colley, 1997; Iroegbu, 1998, QuiaiserPouland and Lehman, 2002; Donnellan, 2003; Hazari and Potvin, 2005; Laura, 2006) on the influence of gender on students' achievement in science subjects particularly in Physics. Iroegbu (2008) discovered that gender effect is significant on achievement in physics. He went further that male students performed significantly better than female students on achievement in physics. Quiaiser-Poul and Lehman (2002) opined similarly that male students performed significantly better than their female counterparts in science. Erinosho (2005) stated that science is a male enterprise.

In contrast, Colley (1997) found that females achieve higher gains in science process in physics in the middle school than their fellow male students. Also, Birch and Sheila (1994) concluded that women have become more prominent in chemistry, biology and physics. Similarly, an anonymous 1996 report for American Physics Society (APS) member stated that women have made modest gains in science. They also discovered that girls performed brilliantly in science classrooms than males students in most of the schools visited. Keeves (1991) and Stephens (1991) also 
documented that disparity existed between male and female student's performance in science subjects. David and Stanley (2000), Arigbabu and Mij (2004) in their findings stated that there are no longer distinguishing differences in the cognitive, affective and psychomotor skills achievements of students in respect of gender.

However, with the conflicting findings on gender related research, it appears that the influence of gender on achievement of students has not been established. Since it has been found that gender factor has positive, negative or no contribution to academic achievement, it is therefore necessary in this study to find out if gender has any effect in this experiment.

\section{Statement of the Problem}

There are many factors that influence enrolment and achievement of students in science and technology subjects. Some of the factors are associated with the nature of the subject matter, students' attitude to the subject and individual characteristics among others. Recently, it has been discovered that instructional methods failure and its ineffectiveness, inability to sustain learner's interest at the early age had been the major causes of the poor achievement recorded in recent times. Teaching science at the early age could pose a challenge, therefore, science and technology teachers teaching young children need to develop a teaching strategy that will facilitate powerful learning experiences which will inspire deeper investigations that will validate and empower children to learn. This study therefore, seeks to investigate the effect of using child-to-child approach, action learning and conventional method in teaching basic science and technology curriculum using the concept of energy on students' learning outcomes. It will also determine the effects of gender on cognitive achievement in basic science and technology curriculum using instructional approaches approach.

\section{Purpose of the Study}

The purpose of the study is to investigate the effect of instructional approaches on pupils' cognitive achievement and attitude in concept of energy. Specifically, the study is designed to achieve the following objectives:

1. To compare the achievement of pupils taught with child-to-child approach, action learning strategy and those taught with conventional strategy

2. To ascertain the effects of instructional strategies on pupils' attitude in the concept of energy.

3. To investigate the influence of gender on pupils achievement in concept of energy when taught using different instructional approaches.

\section{Research Hypotheses}

Based on the purpose of this study, three hypotheses were formulated and tested at the 0.05 level significance.

$H_{0}$ 1: Instructional approaches do not significantly influence pupils' achievement in concept of energy.

$\mathrm{H}_{0} 2$ : Instructional approaches do not significantly influence pupils' attitude in concept of energy.

Ho3: Gender has no significant influence on pupils' achievement in concept of energy when taught using different instructional approaches

\section{Research Method}

The study adopted the pretest-posttest, control group, quasi-experimental design. The participant of the study comprised of all basic level II(primary) pupils in Ifelodun local government area of Kwara State, Nigeria. Random sampling technique was used to select twelve schools that were used for the study.

Twelve schools were randomly selected from the target population. Eight schools were assigned to experimental and four schools to control groups by balloting out of the twelve selected schools respectively.

The instrument used for the collection of data was Basic Science Achievement Test (BSAT) which comprised of 50 multiple-choice item test questions drawn from the approved curriculum. Each item had five options (A - E) with only one correct answer and four distractors. The instrument (BSAT) was validated by two seasoned science educator. 89 questions were initially drawn from the curriculum which was later reduced to 50 items after validation. To further strengthen the suitability of the instrument, the BSAT was administered to a group of 20 pupils who did not participate in the main study, but who were found equivalent in all respect to the pupils used for the main study. The data obtained was analysed using Kuder Richardson formula 21 and a coefficient of internal consistency of 0.78 was obtained. The average 
difficulty and discrimination indices of BSAT items were 0.57 and 0.54 respectively. Based on this, the instrument was found suitable for the study.

In order to ensure teachers quality variables, the research assistants (science teachers used in the selected schools) were trained for two weeks on how to use child-to-child approach, action learning strategy and expository learning strategy (traditional strategy and control ) to teach the concept of energy for the study. The research assistants were given detailed instructions with well-organized lesson plans on the concept to be treated in the curriculum. After the training of the research assistants, the BSAT was administered to the three groups as pretest. After the administration of the pretest treatments were given to the experimental group. In all 194 basic two pupils participated in the study.

The three groups were taught the concept of energy in the curriculum using the same content outline for 8 weeks. The posttest was administered to the two groups after the treatment. The researchers scored the instrument immediately after its administration. Each correct answer was scored 2 marks. The maximum mark for all the fifty item questions was 100 marks. The data collected were analysed using Analysis of Covariance. All hypotheses were tested at the 0.05 level of significance.

\section{Results}

Hypothesis One: Instructional approaches do not significantly influence pupils' achievement in concept of energy. The analysis is as shown in Table 1.

Table 1: Summary of ANCOVA of Posttest Achievement Scores of Pupils using the concept of energy

\begin{tabular}{|c|c|c|c|c|c|c|}
\hline Source & Sum of Squares & DF & Mean Square & $\mathrm{F}$ & Sig. & Remark \\
\hline Covariates & 3991.78 & 1 & 3991.78 & 29.86 & $.00^{*}$ & Sig. \\
\hline Main effects & 85008.05 & 2 & 42504.03 & 318.00 & $.00^{*}$ & Sig. \\
\hline Treatment & 85008.05 & 2 & 42504.03 & 318.00 & $.00^{*}$ & Sig. \\
\hline Explained & 88999.834 & 3 & 29666.61 & 221.917 & $.000^{*}$ & \\
\hline Residual & 25399.836 & 190 & 133.68 & & & \\
\hline Total & 114399.67 & 193 & 592.74 & & & \\
\hline
\end{tabular}

The result in Table 1 shows that there was significant main effect of treatment on students' achievement in the concept of energy $(F(3,190)=221.917, P<.05)$. Therefore, the null hypothesis which stated that instructional approaches do not significantly influence pupils' achievement in concept of energy is rejected. This implies that the posttest scores of pupils' taught differ significantly across the two experimental groups and control. Therefore, hypothesis 1a is rejected. Consequent upon the observed difference in the effect of teaching strategies, Multiple Classification Analysis (MCA) was considered to determine the index of relationship and also to determine the variance of the dependent variable (achievement) in basic science technology curriculum and that is attributable to the influence of the independent variable (teaching strategies) as shown in Table 2.

The Multiple Classification Analysis (MCA) in Table 2 shows the magnitude of the post-test, mean achievement scores of subjects exposed to the different treatment conditions.

Grand Mean $=53.96$

\begin{tabular}{|l|l|l|l|l|l|}
\hline \multicolumn{1}{|c|}{ Variable + Category } & $\mathbf{N}$ & $\begin{array}{c}\text { Unadjusted } \\
\text { variation }\end{array}$ & Eta & $\begin{array}{c}\text { Adjusted for independent } \\
+ \text { covariates deviation }\end{array}$ & Beta \\
\hline Treatment groups & & & & & \\
Child-to-child approach & 59 & 25.63 & & 25.72 & \\
Action Learning & 74 & 2.20 & & -2.13 & \\
Control & 61 & -27.47 & .86 & & .86 \\
\hline Multiple R-squared & & & & & .778 \\
Multiple R & & & & .882 \\
\hline
\end{tabular}

In the table 2, the mean scores of the different treatment groups are: child-to-child approach (79.68), action learning strategy (56.09) and control (26.49) respectively. Hence, it was observed that child-to-child approach had the highest mean score, followed by action learning and lastly control. This shows that the child-to-child group had the highest 
adjusted mean score $(53.96+25.72)$ or $\bar{x}=79.68$, followed by the action Learning group (53.96+2.13) or $\bar{x}=56.09$ and the Control group (53.96 +-27.46$)$ or $\bar{x}=26.50$. The teaching strategies have an index of relationship of $0.78\left(0.88^{2}\right)$, hence the observed relationship in favour of teaching methods, shows that the teaching strategies have a significant relationship of 0.78 (Beta value of $0.86^{2}$ ) with achievement of pupils in the concept of energy. Table 2 also shows a Correlation Coefficient (R) of 0.88 with square coefficient of determination $\left(R^{2}\right)$ of 0.78 . This implies that $88 \%$ of the total variance in the achievement of pupils in concept of energy is attributable to the influence of teaching methods. This implies that the treatment given has significant effect, hence $\mathrm{H}_{01}$ is rejected.

Hypothesis Two: Instructional approaches do not significantly influence pupils' attitude in concept of energy. The analysis is as shown in Table 3.

Table 3: Summary of ANCOVA of Posttest Attitude Scores of Pupils using the concept of energy

\begin{tabular}{|l|l|l|l|l|l|l|}
\hline Source & Sum of Squares & DF & Mean Square & F & Sig. & Remark \\
\hline Covariates & 4180.14 & 1 & 4180.14 & 32.45 & $.00^{*}$ & Sig. \\
Main effects & 21876.94 & 2 & 10938.47 & 84.92 & $.00^{*}$ & Sig. \\
Treatment & 21876.94 & 2 & 10938.47 & 84.92 & $.00^{*}$ & Sig. \\
Explained & 26057.08 & 3 & 8685.69 & 67.43 & $.000^{\star}$ & \\
Residual & 24474.41 & 190 & 128.81 & & & \\
Total & 50531.49 & 193 & 261.82 & & & \\
\hline
\end{tabular}

* Significant at $p<0.05$

Table 3 shows that there is a significant main effect of treatment on students' attitude in the concept of energy $\left(F_{(3,190)}=\right.$ 67.43; $p<0.05)$. The result implies that the posttest attitude scores of the students exposed to the different conditions were significantly different. Thus, the null hypothesis $\left(\mathrm{H}_{02}\right)$ was rejected.

To find the magnitude of the posttest mean attitude scores of subjects exposed to the different treatment conditions, the Multiple Classification Analysis (MCA) presented in Table 4 was computed.

Grand Mean $=73.43$

\begin{tabular}{|l|l|l|l|l|l|}
\hline Variable + Category & N & $\begin{array}{l}\text { Unadjusted } \\
\text { variation }\end{array}$ & Eta & $\begin{array}{l}\text { Adjusted for independent } \\
\text { + covariates deviation }\end{array}$ & Beta \\
\hline Treatment groups & 59 & 9.72 & & 12.07 & \\
Child-to-child & 74 & 5.87 & & 6.20 & \\
approach & 61 & -16.53 & & -19.20 & .82 \\
Action Learning & & & .70 & & .52 \\
Control & & & & & .72 \\
\hline Multiple R-squared & & & & & \\
Multiple R & & & & \\
\hline
\end{tabular}

In the table 4, the mean scores of the different treatment groups are: child -to-child approach (85.50), action learning strategy (79.63) and control (54.23) respectively. Hence, it was observed that child-to-child approach had the highest mean score, followed by action learning and lastly control. This shows that the child-to-child group had the highest adjusted mean score $(73.43+12.07)$ or $\bar{x}=85.50$, followed by the action Learning group $(73.43+6.20)$ or $\bar{x}=79.63$ and the Control group $(54.23+-19.20)$ or $\bar{x}=54.23$. The teaching strategies have an index of relationship of $0.72\left(0.52^{2}\right)$, hence the observed relationship in favour of teaching methods, shows that the teaching strategies have a significant relationship of 0.72 (Beta value of $0.82^{2}$ ) with achievement of pupils in the concept of energy. Table 4 also shows a Correlation Coefficient $(R)$ of 0.72 with square coefficient of determination $\left(R^{2}\right)$ of 0.52 . This implies that $82 \%$ of the total variance in the achievement of pupils in concept of energy is attributable to the influence of teaching methods. This implies that the treatment given has significant effect, hence $\mathrm{H}_{02}$ is rejected.

Hypothesis three: Gender has no significant influence on pupils' achievement in concept of energy using different approaches. The analysis is as shown in Table 5. 
Table 5: Summary of ANCOVA of Posttest gender Scores of Pupils using the concept of energy

\begin{tabular}{|l|l|l|l|l|l|l|}
\hline Source & Sum of Squares & DF & Mean Square & F & Sig. & Remark \\
\hline Covariates & 3991.78 & 1 & 3991.78 & 6.10 & .009 & Sig. \\
Main effects & 1433.68 & 1 & 1433.68 & 2.51 & .115 & n.s. \\
Gender & 1433.68 & 1 & 1433.68 & 2.51 & .115 & n.s. \\
Explained & 5425.46 & 2 & 2712.73 & 4.76 & .010 & Sig \\
Residual & 108974.21 & 191 & 570.55 & & & \\
Total & 114399.670 & 193 & 592.74 & & & \\
\hline
\end{tabular}

* Significant at $p<0.05$

n.s= not significant

The above table showed that there was no significant main effect of gender on pupils' achievement in concept of energy $(F(2,191)=1433.68, P>.05)$. The null hypothesis is not rejected.

Table 6:

Grand Mean $=53.96$

\begin{tabular}{|l|l|l|l|l|l|}
\hline Variable + Category & $\mathbf{N}$ & $\begin{array}{c}\text { Unadjusted } \\
\text { variation }\end{array}$ & Eta & $\begin{array}{c}\text { Adjusted for independent } \\
\text { + covariates deviation }\end{array}$ & Beta \\
\hline $\begin{array}{l}\text { Treatment groups } \\
\text { Gender }\end{array}$ & & & & -2.56 & \\
1. Male $\quad 103$ & -2.64 & & 2.89 & \\
$2 . \quad$ Female & 91 & 2.99 & & & .11 \\
\hline $\begin{array}{l}\text { Multiple R-squared } \\
\text { Multiple R }\end{array}$ & & & & .047 \\
\hline
\end{tabular}

In table 6, the mean scores of the males is 51.32 while that of females is 56.95 . This shows that in the females had a higher mean score than the males respondents.

\section{Discussion}

The data revealed that child-to-child approach is a potential tool that can be used to improve pupils' achievement in primary school (basic level) science. Child-to-child approach was found to be more effective as a teaching strategy than action learning strategy. This might be due to the fact that in child-to-child approach, children are active participants in their own development and the development of others and they are capable of helping themselves and which is more likely that children will gain more from their development if they are active participants. It also focuses on knowledge emerges which lead to the improvement of skills, achievement, self-understanding, self-development and systematic learning occurs which becomes self-sustaining in the long term. The approach was able to reduce the abstract nature of the concept by presenting it real to the pupils.

This study is in agreement with the findings of Hawes (1998), Primore and Stephens, (2000) that child-to-child approach is a viable approach that improves performance, promotes learning It is also a way to develop the capabilities of individuals, good personal behavior and critical thinking. Although, pupils achieved higher in child-to-child approach (79.68) than action learning strategy (56.09) and lastly the conventional strategy (26.49), action learning strategy can equally be used to teach difficult concepts in basic science in a situation where child-to-child approach is not realistic due to certain constraints. Action learning strategy exposes the pupils to more realities of life and tends to work as scientist and acquire knowledge by themselves in which the teacher serves as a guide and correct their misconceptions (Afolabi and Akinbobola, 2009).

From the findings, child-to-child approach can also be used effectively to improve pupils' attitude towards science. This can be attributed to the fact that pupils did all the learning exercise together throughout the treatment period and learners constructed their knowledge at their individual pace. A good number of research works have shown that the information that is self - discovered is best retained (Adesoji, 2003; Ikitde, 2008; Afolabi, 2009). This probably may be responsible for the pupils showing more positive attitude than pupils in other groups.

Data analysis showed that gender has a significant effect on pupils' achievement in basic science curriculum. Female pupils had the higher achievement mean score than their male counterparts. The significant gender related difference in achievement could be explained. Applying appropriate teaching approaches helped female students learn 
and remember facts, apply skill, comprehend concepts, analyses and synthesis principles which are cognitive objective for basic science and technology education. Also, the enthusiasm exhibited by female students who showed zeal when they were taught using child-to-child approach may have led to higher performance at given tasks. This might be due to the fact that female pupils interact better with group member freely and have led to increasing the depth of understanding, enhancing motivation, developing positive attitude toward later use of material presented in the course, develop problem solving skills and generating greater involvement of female pupils than the male with the concept.

The result is contrary with the findings of Akinbobola (2006), Akinbobola (2008) and Afolabi and Akinbobola (2009) that showed no significant difference in the mean performance between boys and girls in the manipulation of the same instructional materials as well as in their rate of contribution and class participation. He noted that every child, both male and female must be given the opportunity to display his/her ability as fully as possible, be they quick or slow, deep or superficial in thinking, once they are taught with the same teaching approach. This is because the good performance of a pupil depends on his interest as well as the techniques used by the teacher and the types of instructional materials involved. The result is consistent with the findings of Dagoli (2000), Ukwungwu and Ezeike (2000) that gender difference really exist in science classroom and that females displayed higher mean scores than their male counterparts when appropriate instructional strategy is used. Jones (1990) concluded that ability correlated significantly with science achievement while gender was not identified as predator of science improvement.

\section{Conclusion}

From the findings, that has clearly shown that child-to-child approach is a good instructional strategy for enhancing the cognitive achievement in science education. It is also a good strategy at enhancing achievement of young people. There is a significant achievement in the performance of female than male taught with the approach. Entertainment education does not only entertain but pass educative messages across to the participants.

Child-to-child approach and action learning strategy is a form of instruction that intensely learners centred, providing personalized learning opportunity oriented to meaningful issues in teaching and learning of science.

\section{Recommendations}

In view of the implications of the findings from this study, the following recommendations are made:

Child-to-child approach should be incorporated in the curriculum as one of the instructional strategies for teaching science education and other subjects at all level of education.

Government should made science more relevant to peoples' lives by providing basic amenities for them and infrastructures.

Science should be made compulsory and taught at all levels of education.

Strategies which will allow participants interaction should be encouraged in schools this will reduce the passive nature of expository strategy which is often used in places of learning.

With the availability of technological software and packages, this will enable learners to have a good learning materials, effective networks and proper support to work at home and according to their pace.

\section{References}

Adesoji, F. A. (2003). Modern strategies in the teaching of integrated science. Teaching strategies for Nigeria secondary schools. S.O. Ayodele (Eds). Ibadan: Power House Press Publishers 205-215

Afolabi, F. (2009). The effects of inquiry-based and competitive learning strategies on academic performance of senior secondary school students in physics. International Journal of Social and Management Sciences, 2 (2), 4 - 10.

Afolabi, F.\& Akinbobola O. A. (2009). Constructivist problem based learning technique and the academic achievement of physics students with low ability level in Nigerian secondary schools. Eurasian Journal Physics and Chemistry Education. 1(1) 45-51.

Ajiboye, J. O. \& Afolabi, F (2012). Health education in context. In NeilTaylor, Michael Littledyke and Richard K. Coll (eds): An international perspective on health education in schools and local communities. Netherlands 145-152. Sense Publishers.

Akinbobola, A.O. (2006). Effects of teaching methods and study habits on students' achievement in senior secondary school physics, using a pictorial organizer. Unpublished PhD. Dissertation. University of Uyo.

Akinbobola, A. O. (2008). Facilitating Nigerian physics students' attitude towards the concept of heat energy. Scientia Paedagogica Experimentalis XLV(2) 353-366.

Akinbobola, A.O (2009). Enhancing students' attitude towards Nigerian senior secondary school physics through the use of cooperative, competitive and individualistic learning strategies. Australian Journal of Teacher Education, 34(1),1-9. 
Alao, E. A. (1990). A scale for measuring secondary school students' attitude towards physics. Journal of Science Teacher Association of Nigeria. 26(2),75-79.

Arigbabu, A. A \& Mji, A. (2004). Is gender a factor in Mathematics performance among Nigerian pre -service teachers? Sex Role $51(11 \& 12), 749$.

Baird, D. (1997). Is physics classroom any place for girls? Unpublished MPhil thesis. University of Michigan.

Birch Ann \& Hayward Sheila (1994). Individual Difference: introductory psychology series. The Macmillian press Itd, Hong kong.

Chambers, A. \& Hale, R. (2007). Keep walking: Leadership learning in Action, RHA publication, UK.

Colley, K. E. (1997). Does the acquisition of science process skills in a project based science curriculum differ by gender? An exploratory study of middle and high school students' experience. Dissertation Abstracts International 57(7), 29-51.

Dagoli, A. J. (2000). The effects of teaching methods on students' achievement in geometry. Journal of Education Studies 4, 81-88.

David, K. D \& Stanley, H. L. (2000). Effect of gender on computer-based chemistry problem solving. Electronic Journal of Science Education 44, 10-14.

Donnellan, C. (2003). Does sex make a difference? An equalities peak for young people on international women's day. The Gender Issues, 64, 14-17.

Ebenezer, J. V. \& Zoller, U. (1993). Grade 10 students' perception of and attitude towards science teaching and school science. Journal of Research in Science Teaching, 30(2), 175-186.

Erinosho, Y. E. (2005). Women and science. 36th inaugural lecture, Olabisi Onabanjo university, Ago-Iwoye 1, 37.

Freire, P. (1970). Pedagogy of the oppressed. New York: The Continuum Publishing

Furner, J. M \& Duffy, M. L. (2002). Equity for all students in the new millennium: Disabling math anxiety. Intervention in School and Clinic 38(2) 67-74.

Hazari, . Z. \& Potvin, G. (2005). Views on female under-representation in physics: retraining women or reinventing physics? Electronic Journal of Science Education,10(1)101-122. Retrieved June 20, 2009 from http://wolfweb.unr.edu/homepage/crowther lelbe/potvin.pdf

Ikitde, G. A. (2008). Comparative effect of riverine and upland schools' location on Biology students' achievement. Sciential Pedagogical Experimentalis XLV. 2267-280.

Iroegbu, T. O. (1998). Problem based learning, numerical ability and gender as determinants of achievements problems solving line graphing skills in senior secondary physics in Ibadan. PhD. Thesis. University of Ibadan, Ibadan.

Jones, J. (1990). Outcomes of girls, schooling: unravelling some social differences. Australian Journal of Education. 3(2),153-167.

Jonassen, D. H. (1991). Objectivism versus constructivism: Do we need a new philosophy paradigm? Educational Technology Research and Development 39, 5-14.

Keeves, J. P. (1991). Sex differences in ability and achievement in Hasten,T. and Postlethwaite.

Kramer, R. (2007). How might action learning be used to develop the emotional intelligence and leadership capacity of public administrators? Journal of Public Affairs Education 13(2), 205-230.

Kolb, D.A(1984). Experimental learning experience as the source of learning and development. Eaglewood cliffs,Newjersey: PrenticeHall.

Laura, A. R. (2006). Why are there so few female physicists? The Physics Teacher, 44, 177-180

Maduabum, M.A.(1991). Primary school science teaching in Nigeria. A need for re-appraisal. Journal of Teacher Education, 1(1),172180.

Marquardt, M.J. (2004). Harnessing the power of action learning. TD, 58 (6), 26-32.

Momoh, A.Y. (2001). Primary education sokoto state. The teacher factor. Journal of Teacher Education, 9(1), 80-86.

Mwebi, B.M. (2012). Teaching HIVIAIDS through a child-to-child approach: a teacher's perspective. Canadian Journal of Education, 35(3)117-132.

Olakulehin, F.K. (2007). Information and communication technologies in teacher traininmg and professional development in Nigeria. Online Journal of Distance Education,8(1),11

Pridmore, P., \& Stephens, D. (2000). Children as partners for health: A critical review of the childto-child approach. London: Zed Books.

Quaiser-Pohl,C. and Lehman, W (2002). Girls' spatial abilities: charting the contributions of experiences and attitudes in different academic groups. British Journal of Educational Psychology 72(2), 245-260.

Sawchuk, P. H. (2003). Adult learning and technology in working class life. NewYork: Cambridge.

Simon, S. (2000). Students' attitude towards science. In M. Monk and J. Osborne (Eds). Good Practice in Science Teaching (What Research has to say). 104-119. Open University Press Buckingham.

Stephen, J. (1991). Impacts of an integrated learning system on third-, foruth-, and fifth- grade mathematics achievement. Doctorial dissertation, Baylor University. Dissertation abstract international, ix+52 pp UMI Number: AAG 9132228).

Sunberg, M. D \& Dini, M. L. (1994). Decreasing course content improves student comprehension of science and attitudes toward science in fresh biology. Journal of Research in Science Teaching. 31(6), 679-693.

Ukwungwu, J. O. \&Ezike R. O. (2000). Gender and physics achievement disparity in Nigeria. A meta-analysis of findings. African Journal of Research in Education.1(1),134-138.

Yoloye, E.A (1994). Primary education. In O.O.Akinkugbe (Ed). Nigeria and Education, challenges ahead. 